\title{
Classification of the flood severity of the Guadalquivir River in the Southwest of the Iberian Peninsula during the 13th to 19th centuries
}

\author{
Leoncio GARCÍA-BARRÓN ${ }^{1}$, Mónica AGUILAR-ALBA ${ }^{2}$, Julia MORALES $^{3}$ and Arturo SOUSA ${ }^{3 *}$ \\ ${ }^{1}$ Departamento de Física Aplicada, Universidad de Sevilla, E-41012 Sevilla, España. \\ ${ }^{2}$ Departamento de Geografía Física y AGR, Universidad de Sevilla, E-41004 Sevilla, España. \\ ${ }^{3}$ Departamento de Biología Vegetal y Ecología, Universidad de Sevilla, E-41012 Sevilla, España. \\ *Corresponding author: asousa@us.es
}

Received: July 31, 2020; accepted: June 15, 2021

\begin{abstract}
RESUMEN
Este estudio estima la severidad de las inundaciones durante los siglos XIII a XIX en el suroeste de la Península Ibérica. Para ello nos basamos en las crónicas históricas de los impactos provocados por las inundaciones del río Guadalquivir en la ciudad de Sevilla (España). La principal fuente documental fue la monografía Historia crítica de las riadas o grandes avenidas del Guadalquivir en Sevilla (1878), que recopila noticias de distintos observadores contemporáneos de cada inundación. Por ello, desde el punto de vista metodológico, ha sido necesario transferir la información procedente de fuentes documentales variadas a índices ordinales, para hacerlas comparables. Esto implica elaborar criterios de asignación por los impactos de las diferentes inundaciones. A partir del índice anual de severidad asignado a cada inundación, se genera la serie interanual. Mediante la ponderación interanual de los índices de inundación se deduce la duración e intensidad de las secuencias de periodos de inundación desde 1250 hasta 1850 . De las 10 inundaciones clasificadas como más destructivas en los cinco siglos estudiados (1280-1880), cinco se concentran en poco más de un siglo, de 1598 a 1701. Los resultados obtenidos contribuyen al conocimiento multisecular de la pluviometría regional y son una nueva aportación a la climatología e hidrología histórica.
\end{abstract}

\begin{abstract}
This study estimates the flood severity between the 13th and 19th centuries on the southwestern Iberian Peninsula based on the historic records of impacts of the Guadalquivir River flooding on the city of Seville (Spain). The main documentary source was Historia crítica de las riadas o grandes avenidas del Guadalquivir en Sevilla (Critical history of the floods of the Guadalquivir in Seville) (1878), which compiles news from different observers that were contemporaries of each flood. Regarding the methodology, it was necessary to transfer the information from different documentary sources to ordinal indices, which required developing allocation criteria per flood impact. From the annual severity index assigned to the different floods, an interannual series was generated. Through interannual weighing of the flooding indices, it was possible to deduce the durations and intensities of sequences of flood periods between 1250 and 1850 . Of the 10 floods classified as most destructive during the five centuries analyzed (i.e., from 1280 to 1880), five occurred during little more than a century (1598-1701). The obtained results contribute to knowledge on regional rainfall, as well as to historical climatology and hydrology, over multiple centuries.
\end{abstract}

Keywords: floods, Guadalquivir River, documentary sources, historical climatology. 


\section{Introduction}

Knowledge on the evolution of climate over past centuries, before instrumental records, is based on multiple sources that provide information directly or indirectly (i.e., proxy data). Historical, botanical, and geological evidence are worthy sources of flood information. Wilhelm et al. (2019) show the historical development of different methodological approaches and the type of information that these files provide. Fundamentally, there are two types of proxy data: natural and documentary data. This study is exclusively focused on proxy data from documentary sources. One of the frequently used types of documentary proxy data is ecclesial documents related to tithe and rogation ceremonies. A tithe payment (i.e., an economic tax of one tenth of a harvest) shows the annual agricultural production associated with meteorological factors, although it is not always easy to interpret. Moreover, in the face of meteorological adversity, the Catholic Church regulated liturgical celebrations of intercession: pro-pluvia rogations, in the case of prolonged droughts, or pro-serenitate rogations, in the case of persistent rainfall with floods (Martín-Vide and Barriendos, 1995; Tejedor et al., 2019). The advantage of the rogation method is that it maintained the spatial and temporal uniformity of the applicable type of ceremony, which indicates the severity attributed to each event (Cremades, 2017).

Other relevant documentary sources of historic climatology are the records and annals of historians who included unique meteorological circumstances in their stories (Rodrigo et al., 2012), minutes of local corporations and institutions that gathered information on exceptional situations such as droughts or floods (Barriendos et al., 2019), and reports of trustees of noble houses about the economic results of agriculture they considered to be affected by meteorological conditions (Fernández-Fernández et al., 2014). This information is frequently scattered and must be filtered from the main focus of the set of consulted documents. In general, literary information on climatic phenomena is linked to the subjectivity and inaccuracy of the chroniclers and may be influenced by external factors. To develop temporal series from this information, it is necessary to establish ordinal levels of intensity that allow the creation of quantifiable scales (Pfister et al., 1999).
Different authors with varied orientations have investigated historical floods in Europe (Brázdil et al., 2006; Glaser et al., 2010; Kjeldsen et al., 2014; Benito et al., 2015; Blöschl et al., 2020), as well as their frequency and intensity in the main Spanish drainage basins (Benito et al., 2003; Machado et al., 2011; Fragoso et al., 2015; Balasch et al., 2019). Regarding the floods of the Guadalquivir River, the geomorphological studies of Uribelarrea and Benito (2008) and Baena et al. (2019) are worthy of mentioning. Despite the large number of historical documents on the Guadalquivir River floods, according to Zamora (2014) the impacts of these floods have not been addressed thoroughly, unlike other European rivers, except the compilation by Francisco de Borja Palomo: Historia critica de las riadas o grandes avenidas del Guadalquivir en Sevilla: desde su reconquista hasta nuestros dias (Critical history of the floods of the Guadalquivir in Seville: From its reconquest to today) (Palomo, 1878). Among the studies focusing on the historic climate of the southern Iberian Peninsula, it is worth highlighting studies on South Portugal (Alcoforado et al., 2000; Do Ó and Roxo, 2008), the Doñana wetlands (Sousa et al., 2010), and southern Extremadura and Andalusia (Rodrigo et al., 1999, 2012; Barriendos, 2007; Rodrigo, 2007, 2017, 2018).

Barriendos and Rodrigo (2006) compared historic floods of the main Spanish drainage basins. According to these authors, it is possible to differentiate the typology between the Atlantic and Mediterranean watersheds, although the drainage basin is the adequate reference unit for the analysis of the chronology of floods. Thus, the Guadalquivir basin, in the South Atlantic side of the Iberian Peninsula, only experienced synchronous catastrophic floods with the Segura basin in 1778 A.D. and with the Douro basin in 1545 A.D. (Fig. 1). García-Codrón (2004) stated that in the Iberian Peninsula, the highest seasonal risk of flooding appears in spring for the central plateau under Atlantic influence (Douro, Tagus, and Guadiana), during autumn for the Mediterranean watershed (Jucar and Segura), and in winter for the Guadalquivir basin. Therefore, this information highlights the need to conduct historical climatological studies that are thoroughly focused on the main basins, such as the Guadalquivir basin object of this study. 


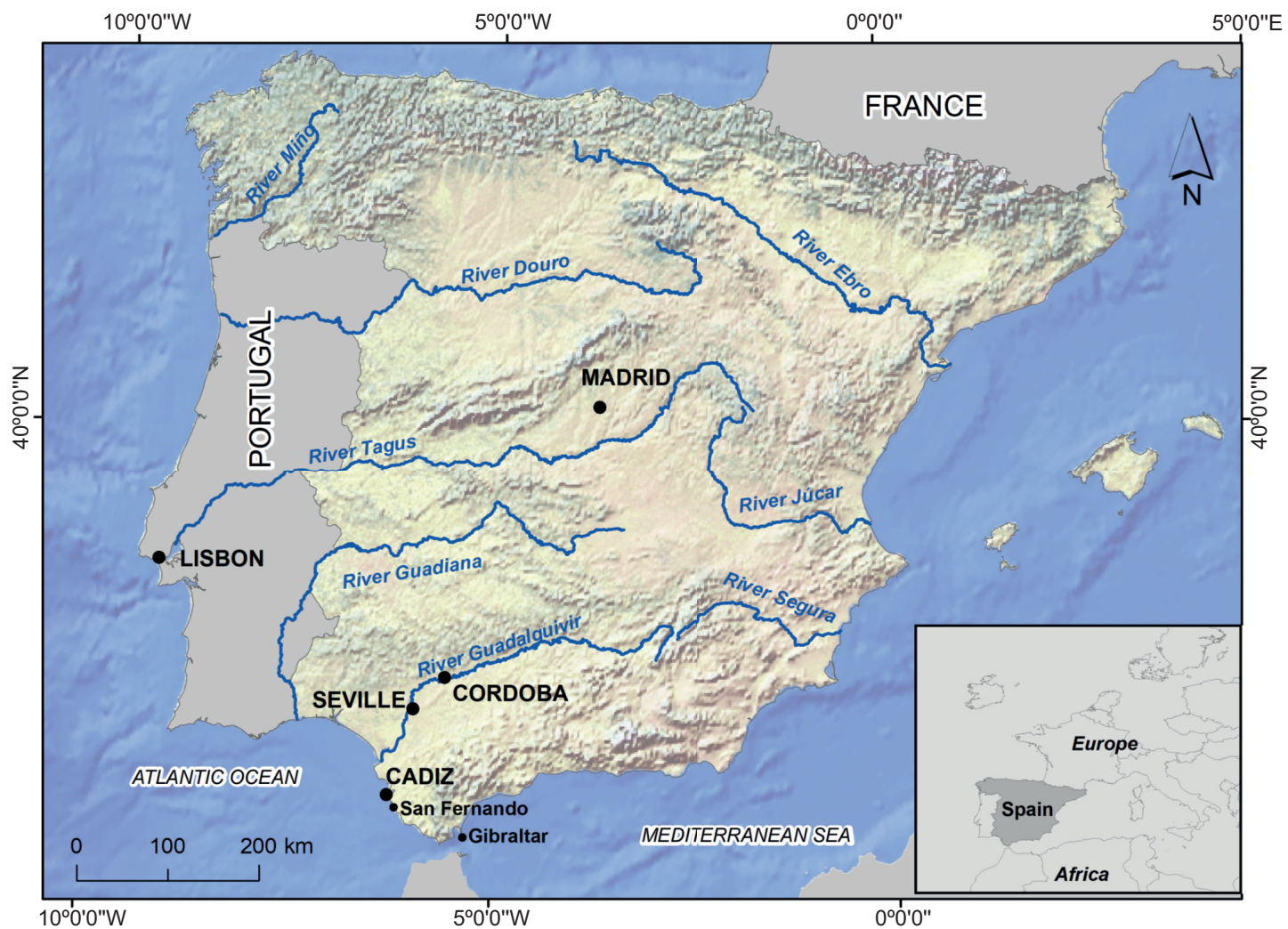

Fig. 1. Location of Seville and the Guadalquivir River on the Iberian Peninsula.

In southern Spain, it is possible to distinguish two causes of flooding:

1. Persistent rainfall due to a long and continuous period of precipitation (or melting) in Atlantic basins, as the Guadalquivir basin. These are more frequent in winter.

2. Torrential rains caused by periods of very intense and short rains. These are frequent in Mediterranean basins as a consequence of cold drops, with greater probability in the months of autumn.

In the Guadalquivir river basin, although floods can be caused by brief torrential rainfalls, they are generally influenced by prolonged and persistent rains, with subsequent runoff from an upper river basin.

The risk of flooding in the Guadalquivir basin is essentially influenced by pluviometric and orographic factors. With respect to the former, it is worth highlighting an important irregularity in precipitation at both the seasonal and interannual scales, with a high frequency of intense rainfall in wide areas of the basin. The annual precipitation average for the entire watershed is of $640 \mathrm{~mm}$. This, however, hides very relevant variations, with over $1000 \mathrm{~mm} \mathrm{yr}^{-1}$ in some areas compared to other areas with only $300 \mathrm{~mm} \mathrm{yr}^{-1}$ (García-Barrón et al., 2011). This is mainly due to frontal precipitation that responds to the entry of Atlantic storms through the Gulf of Cádiz (Vallejo, 2000).

Flooding in the lower Guadalquivir River basin has a high flow rate, which is surprising, given the slight slope in that region and the deceleration exerted by the sinuosities of its course (García, 2003). As stated by Vanney (1970), this scenario is due to the acceleration caused by the local volume contributions.

The aim of this work is to classify the floods of the Guadalquivir River in the city of Seville from the 13th to the 19th century using historical records gathered by Palomo (1878). 


\section{Study area and data}

The following sections describe the urban circumstances of the city and its relationship with the river to better understand the subsequent categorization of the impacts caused by the floods of the Guadalquivir River on the city of Seville. Most of the studies that analyze the floods of the Guadalquivir focus on their effects on the urban transformation of Seville and on hydraulic works during the 19th and 20th centuries (del Moral, 1991, 1992). On the other hand, studies of the floods of previous centuries are very scarce. We analyze the main source of documentary proxy data used in this study (Palomo, 1878) that were subsequently compared with instrumental meteorological data.

\subsection{Study area: The city of Seville and its relations- hip with the floods of the Guadalquivir River}

The Guadalquivir River is the most important river in the southern part of the Iberian Peninsula $(657 \mathrm{~km}$ long). It crosses Córdoba and Seville (Fig. 1) and discharges in Sanlúcar de Barrameda, next to Doñana National Park. The Guadalquivir River is situated in the southwest of Spain, where there is a Mediterranean climate influenced by the Atlantic Ocean (García-Barrón et al., 2013).

The city of Seville $\left(37.38^{\circ} \mathrm{N}, 5.97^{\circ} \mathrm{W}\right)$ is built on an alluvial plain. Historically, it was a walled city surrounded from the northeast to the southwest by the Guadalquivir River (Fig. 2). This river separates the traditional neighborhood of Triana from the remainder of the historic urban center of Seville. Therefore, the extramural neighborhood of Triana was connected to the intramural area of the city of Seville by a floating (or pontoon) bridge that crossed the Guadalquivir River (Fig. 2). This floating bridge, originally built in 1171 A.D., consisted of a set of tall boats anchored to the bottom, joined together by iron chains, with wooden columns that held the platform of the bridge. By observing old lithographs, it is possible to deduce that the distance between the water surface and the platform of the bridge was no more than two and a half meters. It was reported that the bridge was damaged several times and even ripped and broken apart by the current in 1794 (Palomo, 1878).

The walls of the city of Seville have historically served two defensive purposes: military and hydrological. The initial construction of the wall dates from the period of Julius Caesar (1st century B.C.). Since the Roman Age, it has been rebuilt and expanded. In the late Middle Ages, the wall was $7 \mathrm{~km}$ long and had 166 turrets, with 19 gates and wickets. Since the 16th century, its military purpose has been less important, and it was maintained to protect the city against the flooding river. It is the fundamental protective element of the city. During flood events, its

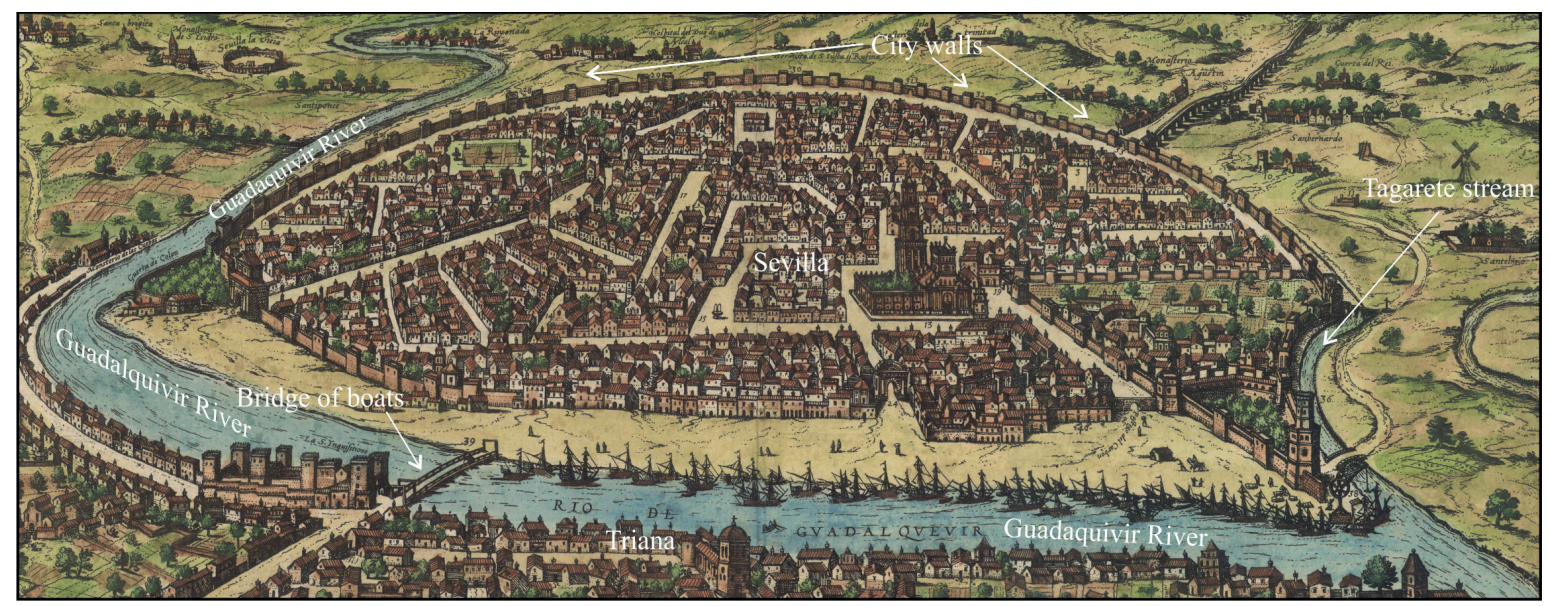

Fig. 2. View of Seville with the Guadalquivir River in the 17th century. This map shows the floating bridge or bridge of boats at the lower left side and the Torre del Oro at the right end of the harbor. Source: detail of the enlarged facsimile version of Braun and Hogenberg, Civitates Orbis Terrarum (1588). It can be found online at the National Geographic Institute of Spain: https://www.ign.es/web/catalogo-cartoteca/resources/html/023677. html (accessed on April 16, 2020). 
gates were externally reinforced with caulked planks inserted in lateral guides. It is important to highlight that in 1868 , after great political debate, the gates and walls were torn down with the justification that this would favor the expansion of the city. However, this would also influence the impact of floods on the city, as described in subsequent sections.

Similarly, the drain spindles of the city of Seville were closed during floods to prevent them from working in the reverse direction (i.e., introducing water from outside of the city into the walled urban center). In the river plain of the opposite riverbank, next to the neighborhood of Triana, cloisters and monasteries were built, which appear frequently in historical records as being affected by river flooding. After floods, a serious additional problem was the permanent ponding of the low areas of the river plain, where poor quality water bodies formed, with pests and the risk of disease transmission, as was reported for different periods by Palomo (1878).

Two tributaries flowed through the west side of the city, which are currently channeled and hidden: the Tamarguillo, currently a ring road for traffic, and the Tagarete, closer to the walls (Fig. 2), which crossed under the bridge that provided access to the Xerez Gate in the southwest of the city. This location is very relevant since the height of the old city wall is a reference used by some chroniclers to alert about the danger of floods. Both tributaries increased the destructive flood effects on the city. Moreover, Guadalquivir River is influenced by the rhythm of the tides at its mouth; high tides oppose the flow of the river current, which hinders river discharge during floods.

In the 7th century, the old canal of La Vega was opened to serve as a natural drain that prevented the risk of overflow into the city and that was maintained and improved during Muslim rule. However, with the Christian reconquest (13th century), the maintenance of the canal was neglected, and its depth decreased, which increased the flood risk. During the 17th-19th centuries, important containment and diversion works were proposed, although most of them were never implemented.

In 1776 the sewerage system was enhanced and a pier was built that improved the defense of the city against floods. In 1816, different reformations were carried out along the course of the Guadalquivir
River between its mouth and the city of Seville to facilitate navigation throughout the river and reduce the risk of flooding.

It is worth mentioning the severe floods of 1892 and 1895 , when the city was not protected by the wall. In the 20th century, several overflows also occurred, generally with small impacts, of which there is extensive journalistic and graphic documentation. During the 19th century and especially the 20th century, hydraulic works were carried out in the river and in the flood plain, such as the cutting of meanders and canals or reservoirs (García-Martínez and Baena, 2006), which have substantially modified the natural dynamics of the river and the risk of flooding.

\subsection{Historical documentary sources}

The present study is fundamentally based on the documentary proxy data obtained from the historical monograph by Palomo (1878) (Fig. 3), who gathered data on the historical floods of Seville and their effects on the city between the 13th and 19th centuries, and for all years with floods, he compiled all the known documentary sources. Francisco de Borja Palomo was a scholar and bibliophile, professor of jurisprudence at the University of Seville

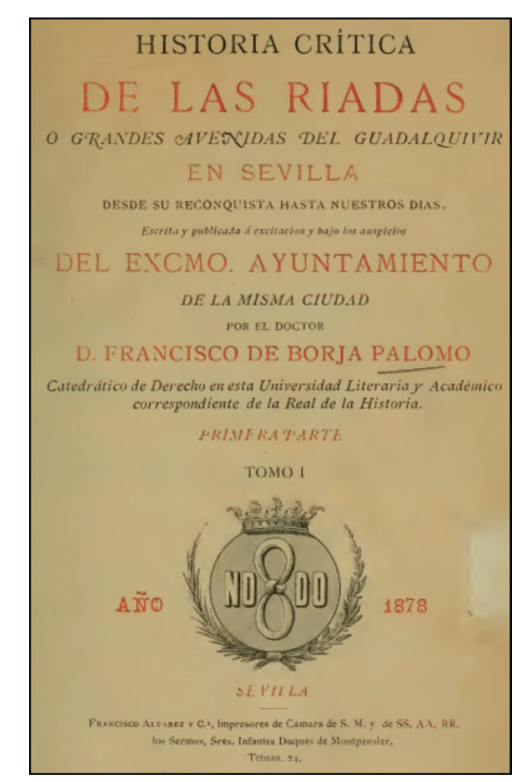

Fig. 3. Original cover of Historia crítica de las riadas o grandes avenidas del Guadalquivir en Sevilla, vol. I, published in Seville in 1878. 
and official receiver of the city hall of Seville in the late 19 th century. In addition to the detailed critical compilation of annual floods, he also included notes, biographical comments of distinguished figures, descriptions of relevant and catastrophic events (earthquakes, hurricanes, epidemics, famines, etc.) and a description of some monuments. He provided paintings with a view of the city and its relationship with the river, as well as images of the old gates of the city wall. His complex book is divided into two volumes. The first volume covers the period between the Christian Reconquista (13th century) and 1800 A.D. and compiles and expands upon the articles that were previously published by the author. The second volume is focused on the 19th century and was published later (1884), incorporating other manuscripts. In each of the years when there were reports about floods, the book includes comments on the primary documents written by chroniclers who were contemporary to the event or had direct references. Similarly, the second volume includes texts of historians who highlighted the effects of the floods with a broader perspective. We have consulted primary sources in files and historical records of different institutions that corroborate the reliability of the corresponding comments by Palomo (1878). As an interesting example, we highlight the dissertations presented at the Regia Sociedad de Medicina y Ciencia of Seville after the floods of the 18 th century, focused on the medical damages that floods can cause.

Data of Palomo (1878) have been used in studies that analyze changes in the geomorphology of the Guadalquivir River during the Holocene (Uribelarrea and Benito, 2008), the sinking of the flood plain as a consequence of the growth of the city of Seville (Ruiz-Constán et al., 2017) and the flood risk of the Guadalquivir River (García-Martínez and Baena, 2006), as well as the fact that it has been cited as a source of studies on historical floods in Andalusia in the 16th century (Pfister et al., 1999) and throughout the 20th century (León et al., 2020).

One of the most laborious tasks involved in acquiring information related to historical climatology and hydrology is consulting multiple documents with varied content in archives and libraries of diverse ownership. Palomo (1878) gathered over 400 works, most of them related to the history of
Seville and the floods of the Guadalquivir River: records, annals, memorials, ephemerides, relations, appendices, speeches, dissertations, etc., of numerous authors throughout history. Among this vast number of documents, he highlighted, based on the number of citations and the authority granted to its comments, the Ecclesiastical and secular annals of Seville by D. Diego Ortiz de Zúñiga (1638-1680). This author gathered, in his memoirs, data on the period between 1246 and 1671 A.D. According to León et al. (2020), the book of Palomo (1878) is a bibliographic source of inestimable value for its clarity and detailed information. It is also cited in the National catalogue of historical floods of Spain (DGPCE, 2019).

\subsection{Links of floods with meteorological instrumental records}

Similarly, the Royal Institute and Observatory of the Navy of San Fernando (Cádiz, southwestern Spain) has uninterrupted pluviometric records from 1805 , although with homogeneous monthly series from 1837. It is considered as a reference observatory due to the homogeneity of its temporal series, which is the longest series for southern Spain (Rodrigo, 2002; Sousa et al., 2010). A recent study, which analyzed 25423 pluviometric observatories in 32 geographical areas worldwide, highlighted that the observatory of San Fernando has the longest uninterrupted daily series (Morbidelli et al., 2020). San Fernando is not located in the Guadalquivir Valley (it is $30 \mathrm{~km}$ away from the mouth of the Guadalquivir River), although it is in the same drainage basin, i.e., the Andalusian South Atlantic basin. Different authors have applied the evolution of monthly precipitation series of San Fernando as an indicator for the entire southwestern region of the Iberian Peninsula (Sousa et al., 2009, 2015; García-Barrón et al., 2013, 2018). During the 19 th century, reports about floods partially overlapped with the instrumental rainfall records of the observatory of San Fernando.

After the summer period, in which the monthly precipitation of July and August is frequently null, the precipitation of the beginning of autumn is incorporated into the subsoil; therefore, except for occasional torrential rains, the runoff of streams and the flow in the tributaries of the Guadalquivir does not present a notable increase until the end of autumn. 


\section{Methodology}

3.1 Methodology used to estimate the severity of the floods between the late 13th century and the 18th century

To calculate the severity of floods reported between the 13th and 18th centuries, so that the severity values can be compared, we must standardize the information obtained from documentary sources of different origin (by author, date and content). Thus, we established source-contrast systems that allowed the subsequent classification of very different flood events, selecting the following main criteria: (a) the height reached by the overflow on the wall or on one of the gates of the city, (b) the damage caused by the collapse of buildings, and (c) the number of people drowned.

Other secondary criteria to standardize the range of severity of the floods were: (a) the evacuation of exterior buildings (private homes and cloisters), (b) livestock mortality in the flood plain of the Guadalquivir River in the vicinity of Seville, (c) effects on the floating bridge or on the ships of the harbor, and (d) rogations and other religious ceremonies.

Apart from these criteria, and with the aim of establishing the severity of the flood events, we used a triple filter that modulated the classification assigned to them by different documentary sources, in order to compare their severity levels:

- The relevance of the social and urban impacts in the urban area of Seville with which they appear in the compilation of events conducted by Palomo (1878).

- The appreciation of the authors themselves and the comparison with similar events gathered in records and annals of long periods.

- Whether they were gathered in the main records or only in particular references.

Appendix 1 in the supplementary material shows, in a comparative manner, the main and secondary criteria employed to assign the overflow level and impact of different flood indices, as well as the filters applied to modulate the classification of the severity of floods.

Guided by these criteria, we assigned an ascending index of flood severity as a function of the level of the overflow and its impact:
- Flood I. Flooding with the gates and spindles of Seville being closed and flooding of the extramural neighborhoods, with the evacuation of the flood plain of the Guadalquivir River in the vicinity of Seville.

- Flood II. Alarm in the city with the rampart or gates endangered, collapsed buildings and flooding in the lower intramural areas.

- Flood III. Serious generalized catastrophic situations in the entire city, except in higher areas.

Each of the testimonies about specific events highlights some of the above-mentioned aspects, without the possibility of establishing a common typology. Thus, it was necessary to conduct a comparative evaluation of the information provided in each case. We recognize that the application of the previous criteria to each year with a registered flood is subject to personal valuation margins of the authors of the original documentary sources. To control this subjectivity, the descriptions of the different documentary sources were transformed into numerical tables based on the flood indices (see Appendix 2 in the supplementary material). Other documentary sources consulted can be seen in Appendix 3 in the supplementary material.

\subsection{Methodology used to calculate the severity of} the floods reported in the 19th century and their relationship with instrumental meteorological records The second volume of Palomo (1878) is focused on the floods that took place in Seville during the 19th century. The information provided by different documents compiled by this author is not uniform throughout the 19th century. The description about the effects of the overflow cannot be directly compared to those in previous centuries, mainly due to the large construction works carried out in 1776 with the building of a pier in front of the walls, and later in 1816 with the construction of a canal that reduced the risk of flooding. Thus, these elements modified the severity of the impacts that served as classification criteria in this study for previous centuries.

The average of the instrumental series from the 19th century shows that in the Guadalquivir River Valley, the intra-annual distribution of precipitation increases in autumn until it reaches a monthly maximum in November-December and decreases 
progressively in spring (García-Barrón et al., 2013). The interannual variability of the seasonal changes of the precipitation regime is associated with the North Atlantic Oscillation (NAO) in the Iberian Peninsula (Trigo et al., 2004), which, in its negative phase, favors the entry of storms in the Guadalquivir River Valley (Gallego et al., 2006; García-Barrón et al., 2018). This current behavior can be extrapolated to previous centuries (Luterbacher et al., 2002).

During the first half of the 19th century, the classification of the severity of floods of the Guadalquivir River was based on the description of the effects caused by the floods. However, from 1858 to the end of the 19th century, we generated a quantified series of river overflows that allowed us to establish the possible degree of synchronous correspondence between the temporal series of both climatic manifestations: precipitation vs. overflow. For each flood, we identified the height of the river over the usual level. In the Guadalquivir River basin, floods are generally due to persistent rainfall and not to very short and intense rainfall events. This period of persistent rains precedes the more intense rainfall that ends up leading to the overflow of the channel. According to the revised historical documentation, in the surroundings of Seville, the floods used to last several weeks. For this reason, we used the data for the month in which the maximum overflow occurred and also the data for the previous month (bimonthly). For that reason, the meteorological variable used for the correlation test was the excess of bimonthly precipitation at San Fernando with respect to the average of the period 1837-1890.

To synthesize the temporal development, we generated a new series, based on the flood index, that shows the rainy sequences or periods between the late 13th and 19th centuries using the centered moving average calculated for $11-y r$ periods. In general, from the 16 th century the number of documentary sources available for the same event has progressively increased. This means that the information available is also greater, which does not necessarily imply that the number of floods is therefore more frequent or intense.
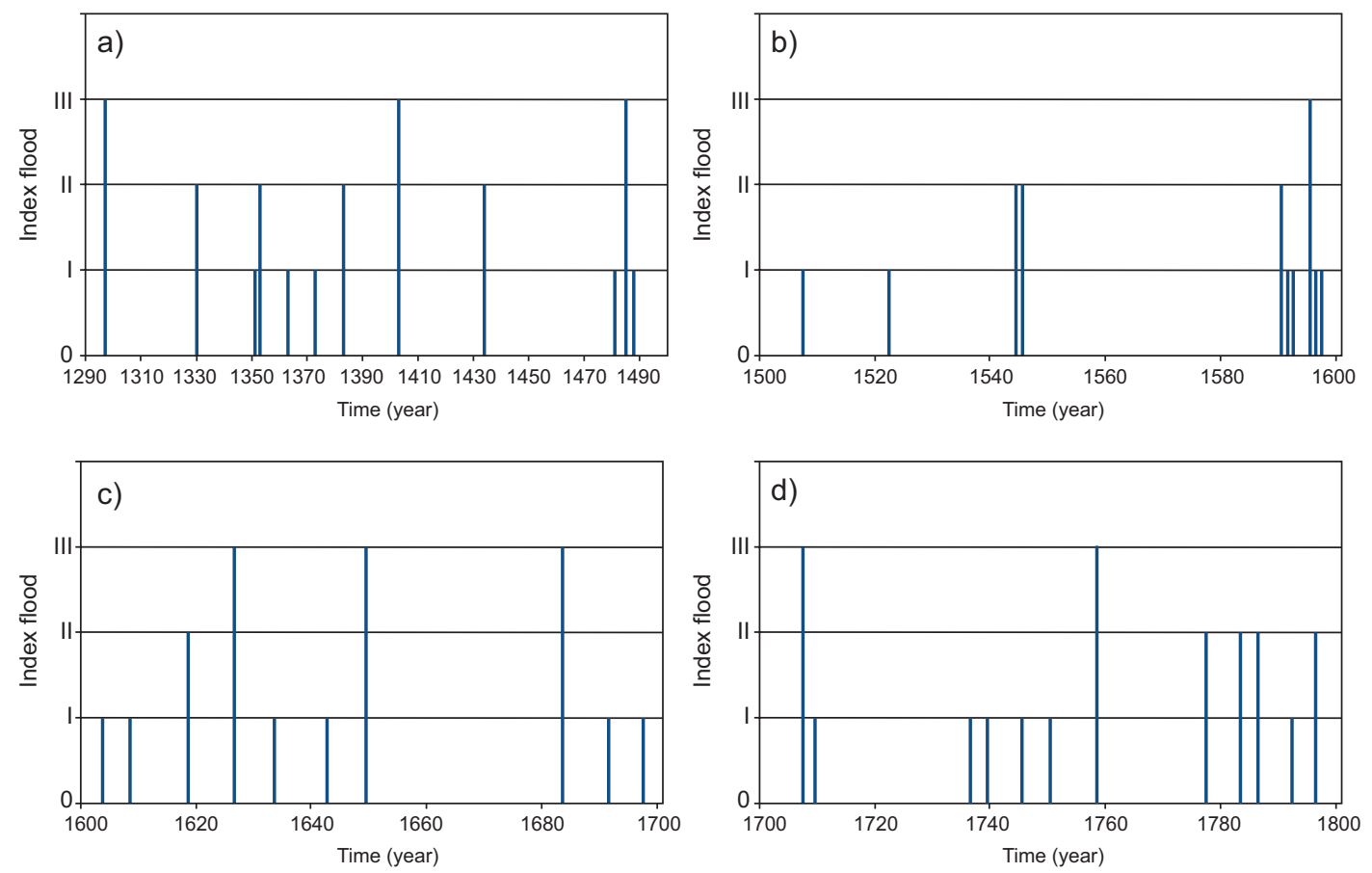

Fig. 4. Flood index estimated for the Guadalquivir River in Seville: (a) 1290 A.D. to the 15th century, (b) 16th century, (c) 17th century, and (d) 18th century. 


\section{Results and interpretation}

4.1 Severity of the floods between the late 13th century and the 19th century

A classification of the Guadalquivir River floods, based on the flood severity index assigned, between 1290 A.D. and the late 18th century is shown in Figure 4. Although there is temporal continuity, to visualize the flood events in more detail, they were grouped by century. More specifically, Figure 4a represents the 13th, 14th and 15th centuries; Figure 4b shows the 16th century; Figure $4 \mathrm{c}$ displays the 17th century; and Figure $4 \mathrm{~d}$ shows the 18th century.

\subsubsection{3th-15th centuries}

Despite the limited number of authors and the difficulty in preserving documents disseminated by copyists before the arrival of printing, news of floods before 1500 A.D. have been transmitted. Some of these reports are focused on the spread of diseases rather than on direct property damage. We interpreted that because this information had been recorded as extraordinary events by chroniclers, they were relevant.

In the 250 years of the late Medieval period ( 1250 to 1500 A.D.), 12 floods of remarkable impact were described (Fig. 4a). Three of them were classified as extremely disastrous (indexed as Flood III), specifically in 1297,1403 and 1485 . Before 1290, there are no records of floods in the book of Palomo (1878). During the first half of the 14th century, the incidence of floods was very low, and then, in the second half, there were floods of different categories.

Between the floods of 1403 and 1481, only that of 1435 was reported, which suggests that the pluviometric regime for that period in the Guadalquivir River valley was characterized by scarce overflow. Considering the number and effects of the floods, we can estimate that globally, over the studied time period, the 15th century, except for the two last decades, was the period with the lowest flood incidence.

\subsubsection{6th century}

Ten floods were recorded throughout the 16th century, although six of them took place in the last decade of that century. The flood reported in 1595 was classified as a generalized catastrophe in the city (indexed as Flood III). This suggests that the last decade of the 16th century was very rainy and that the remainder of the century had very few flood events.

\subsubsection{7th century}

Although only 10 floods were reported in the 17th century (in 1626, 1649, and 1683), these floods can be considered among the most catastrophic floods during the analyzed centuries (indexed as Flood III). Except for 1650-1682, in which no overflow of the Guadalquivir River was recorded, the remainder of the century presents a relatively uniform distribution, with a trend of approximately 7-10 yrs. Precisely, this period of 1650-1682 coincides with the first half of the Maunder minimum (1645-1715) (Eddy, 1976; Usokin, 2017) which, under our criteria, supports the idea that the decreased insular activity corresponded to a dry period in southern Spain, although the continuity of the Maunder minimum from 1683 to 1715 was relatively more humid (Alcoforado et al., 2000).

Through the analysis of the ecclesiastical tithe between 1589 and 1708, Rodrigo (2007) established that in the area of Seville, 30 years of bad harvests were recorded, of which 16 could be attributed to excess precipitation, among other possible causes such as frost and locust plagues and the Plague epidemics. In the same period, 19 floods of different categories were recorded. Over nine years, the excess rainfall coincided with floods. However, among the bad harvests, such analysis did not include the serious floods of 1595 and, especially, 1626; the latter was called "el año de diluvio" ("the year of deluge"). No floods were recorded in any of the seven years classified as bad harvest years.

The solemn public supplications are important means for understanding the historical evolution of the climate. In the investigations based on ecclesial documents they take on a remarkable weight. Although Palomo (1878) collects multiple news on supplications related to the Guadalquivir River, his analysis is even broader, since he also includes other documentary sources that directly describe the level reached by water in each flood and its urban and social impacts.

\subsubsection{8th century}

Twelve overflows of the Guadalquivir River occurred in the 18th century, and those in 1707 and 1758 had catastrophic effects (indexed as Flood III). During the second half of the 18th century, the occurrence of moderate and serious events increased (indexed as Floods II and III). García-Martínez and Baena 
(2006) also found an increase in the frequencies of Guadalquivir River floods from 1750 with respect to the previous centuries. The greatest rainfall variability was detected in 1730 and 1780 . The first years of the 1780 s were very dry; during the winter and spring of 1780-1781 and the spring of 1782, there were marked episodes of drought, as confirmed by the pro-pluvia rogations. On the other hand, strong rains prevailed from 1784 (when the floating bridge of the Guadalquivir River was moved) onwards.

In summary, Table I shows the number of reported floods between 1280 and 1800 as a function of the flood impact index assigned, the probability of occurrence per decade and the average period of recurrence in years.

Table I. Distribution of floods based on the annual index flood, with probability of occurrence and average recurrence period.

\begin{tabular}{lccc}
\hline $\begin{array}{l}\text { Flood } \\
\text { index }\end{array}$ & Number & $\begin{array}{c}\text { Average } \\
\text { probability of } \\
\text { occurrence per } \\
\text { decade }\end{array}$ & $\begin{array}{c}\text { Average } \\
\text { recurrence } \\
\text { period } \\
\text { (years) }\end{array}$ \\
\hline I & 23 & 0.44 & 22.6 \\
II & 12 & 0.23 & 43.3 \\
III & 9 & 0.17 & 57.8 \\
Total & 44 & 0.85 & 11.8 \\
\hline
\end{tabular}

Table I shows that, on average, the city of Seville has had approximately one flood every 12 years, of which one every 58 years had catastrophic effects. Therefore, it is possible to confirm that the flood risk in the urban area of Seville was a historically usual element. Thus, flooding was a consistent focus and concern for the authorities and the population.

\subsection{Severity of the floods during the 19th century} Section I of volume II (1800-1858) of Palomo (1878) describes 10 overflows of the Guadalquivir River. The recorded documentary sources differ in the type of information they provide in different years, although they are consistent in the use of platforms ("borriquetes" in Spanish) raised above the floating bridge of the Guadalquivir River to connect to the neighborhood of Triana (1803, 1830, and 1841). In January 1823, the main catastrophic flood of this period took place, which inundated the entire neighborhood of Triana and reached the height of the previous great flood of 1796 . We can assert that in the first half of the 19th century, the frequency of floods of different intensities was high. Section II describes historical episodes of the city that were not directly related to the river flooding. As a novelty, section III provides uninterrupted data from 1858 on the height (feet) reached by the river during each flooding event. Table II shows the years and months of maximum overflow and the corresponding elevation over the usual level of the river.

Moreover, as noted in the methodology section, we used the monthly rainfall series of the San Fernando Observatory (southwestern Spain) to calculate the bimonthly excess precipitation with respect to the average of that in 1837-1890, coinciding with the floods. The flood of 1876-1877 was not used in the calculations since after the demolition of most of the gates and the walls of the city in the preceding years, the river flooded the city. Therefore, without protection, there was no longer a uniform criterion to compare the effects of previous floods.

Figure 5 shows a pair diagram between the synchronous series of bimonthly excess rainfall $p$ $\left(1 \mathrm{~m}^{-2}\right)$ and the overflow level $d$ (inches). Although the number of data points is small, it can be observed that the dots are roughly aligned.

Table II. Month and year of the most relevant floods and the corresponding elevations of the level of the river (in inches).

\begin{tabular}{lcccccc}
\hline Date & $\begin{array}{c}\text { November } \\
1858\end{array}$ & $\begin{array}{c}\text { December } \\
1860\end{array}$ & $\begin{array}{c}\text { January } \\
1862\end{array}$ & $\begin{array}{c}\text { January } \\
1867\end{array}$ & $\begin{array}{c}\text { January } \\
1872\end{array}$ & $\begin{array}{c}\text { December } \\
1876^{*}\end{array}$ \\
\hline $\begin{array}{l}\text { Elevation of the level } \\
\text { of the river }\end{array}$ & 21 & 12 & 16 & 28 & 22 & 37 \\
\hline
\end{tabular}

*The impacts of this year cannot be compared with the other floods of the 19th century. 


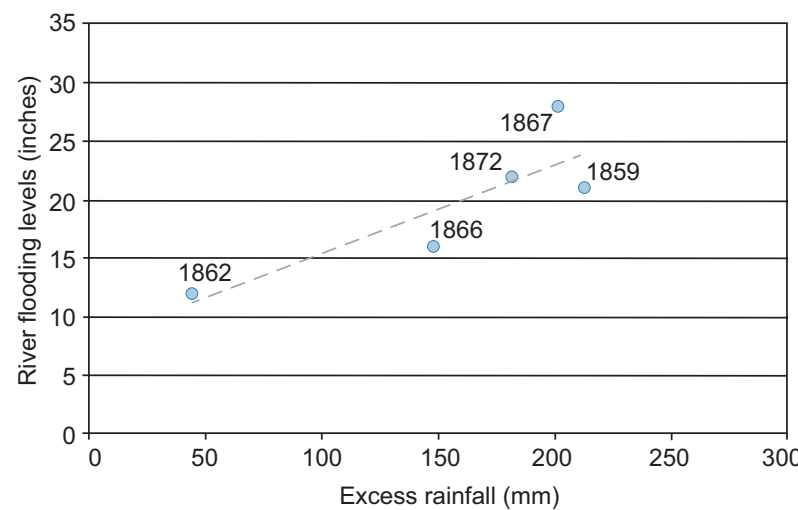

Fig. 5. Scatter plot of the elevation of the river level, measured in inches, and bimonthly excess rainfall, measured in millimeters, with the regression line indicated.

The small number of events and the type of variables that led to Eq. (1) do not allow extrapolation to previous centuries, although $\mathrm{R}^{2}$ explains more than $70 \%$ of the variance (Pearson's correlation coefficient $\mathrm{R}=0.84, \mathrm{p}=0.073$, and the standard error of the estimates is 3.78).

$p=9.4 d-28.5$

The average of the instrumental series from the 19th century shows that in the Guadalquivir River valley, the intra-annual distribution of precipitation increases in autumn until it reaches a monthly maximum in November-December and decreases progressively in spring (García-Barrón et al., 2013). The precipitation regime is associated with the NAO in the Iberian Peninsula (Trigo et al., 2004) which, in its negative phase, favors the entry of storms in the Guadalquivir River valley (Gallego et al., 2006;
García-Barrón et al., 2018). This current behavior can be extrapolated to previous centuries (Luterbacher et al., 2002). Figure 6 shows the intra-annual rainfall distribution (Fig. 6a) and the intra-annual distribution in the number of floods (Fig. 6b), exhibiting the delay in the month with the highest probability of floods (January) with respect to the maximum of the intra-annual rainfall distribution (November-December). This could be due to the fact that floods are frequently influenced not only by immediate direct rain but also accumulated rain in a drainage basin.

Between the starting date of the uninterrupted instrumental series of rainfall records (1837) and the year of the last reports about floods gathered by Palomo (1878), the following is observed:

- In each of the 16 years with floods (see Appendix II in the supplementary material), the total annual precipitation was above the average precipitation of the entire period.

- The average annual precipitation of the years with floods was $847 \mathrm{~mm}$, which is significantly different from the average of $580 \mathrm{~mm}$ for the entire period $1837-1878$, that is, $46 \%$ over the annual arithmetic mean of the same period.

- For this period the average rainfall in the two wettest months of the year was $125 \mathrm{~mm}$ in November and $119 \mathrm{~mm}$ in December. However, in the years with floods the average of the month when the flood occurred was $143 \mathrm{~mm}$ and the average of the previous month was $184 \mathrm{~mm}$. Therefore, the excess of the bimonthly accumulation corresponding to flood events is $35 \%$ higher than that of the wet bimesters.
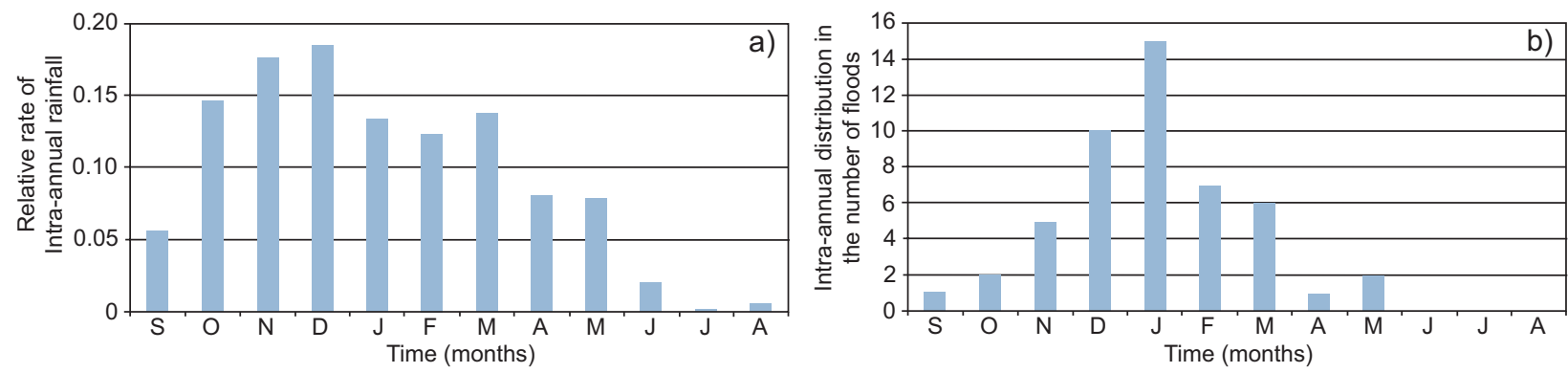

Fig. 6. Intra-annual distribution: (a) relative rate of monthly rainfall during the instrumental period and (b) intra-annual distribution in the number of floods. 
4.3 Interdecadal-scale estimation of the pluviometric evolution in the Guadalquivir River basin based on the records of floods in Seville

Frequently the floods of the Guadalquivir River are due to the accumulation of intense rains for several days in the context of a wide period of some weeks with rainy conditions. In general, this type of temporary distribution of rainfall is usually associated with the existence of west-south-west Atlantic fronts.

Using the results obtained in sections 4.1 and 4.2, it was possible to generate an inter-annual series of the flood index from the 13th to the 19th century. From the results of the annual flood indices for 1297 1796 (Fig. 4 and Appendix II), the centered moving average was calculated for 11-yr periods (Fig. 7). The values of the $Y$ coordinate represent the temporal variation of the flood index. This allows to establish a comparable ordinal scale for more than five centuries, which estimates the historical evolution of floods in the southwestern Iberian Peninsula.

Figure 7 shows a non-periodic alternation of years with flooding and non-flooding intervals. During the 14th century, a moderate level of floods can be observed; however between 1580 and 1650 there is a long sequence of flooding. Finally, from 1680, three discontinuous pulses are shown with a greater amount of flooding episodes: 1680 to 1710,1730 to 1760 , and 1770 until the end of the 18 th century.

Rodrigo et al. (1999) presented conclusions on the temporal development of precipitation in southern Spain based on several types of historical reports in different localities between 1500 and 2000, with instrumental records for the 19th and 20th centuries. We observed a generalized likelihood between their pluviometric evolution and the one obtained in the present study for the same periods in both studies (1500-1800 A.D.). The authors highlighted the positive anomaly or the humid period from the late 16 th century to the mid-17th century.

Through a documentary analysis of institutional sources and ecclesiastic pro-pluvia rogations, Barriendos (2007) used two complementary ordinal indices of precipitation and drought. This author highlighted that in Seville, two periods of floods, one from 1580 to 1620 and the other from 1760 to 1800 , occurred. He also identified two drought periods: 1560-1580 and 1660-1730. Generally, his results are globally consistent with those presented in this study, with no discrepancies at the multi-decadal scale. The results obtained by García-Martínez and Baena (2006) from a geomorphological analysis of the study of floods in the lower Guadalquivir River are also in line with our results.

It seems probable that the effects of the Little Ice Age (LIA) on the Mediterranean latitudes were markedly more humid and with greater variability with respect to those on the northern latitudes of Europe (Sousa and García-Murillo, 2003). Pfister et al. (1999) stated that climate change on the Iberian Peninsula could be more associated with precipitation and less associated with temperature. Grove (2001) highlighted that the same climatic conditions that induced the advance of glaciers during the LIA were also responsible for an increase in the frequency of

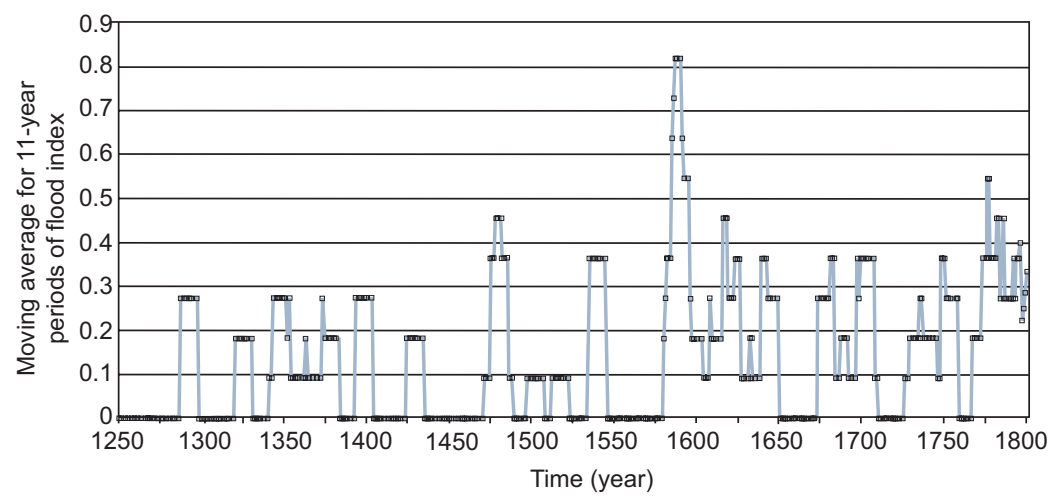

Fig. 7. Decadal-scale estimation of the flood index evolution in the Guadalquivir River basin based on the flood records for Seville between 1250 and 1800 A.D 
floods and sedimentation in Mediterranean Europe. Several studies (Barriendos and Martín-Vide, 1998; Rodrigo et al., 1999, 2000) detected, with different aspects, humid periods during the LIA in Andalusia (1570-1630, 1780-1800, and 1830-1870), which alternated with dry periods and with great variability (Benito, 2006; Rodrigo, 2018). Similarly, different studies have detected greater aridity in the climatic conditions of the Doñana biosphere reserve, which coincided with the end of the last of the humid periods of the LIA on the southern Iberian Peninsula, and these conditions influenced the deterioration of lagoons (Sousa et al., 2010), hygrophytic plants (Sousa et al., 2013) and coastal streams (Sousa et al., 2015).

In comparison with other studies, based on different types of qualitative sources of information and through different assignation procedures, the results of this study must be interpreted in their own context. The concept of drought can result in multiple interpretations in general, which refer to a deficit of precipitation. Therefore, although different authors that documented historic climatology used terms that, in a simplified manner, identify with dry/rainy, these do not have an unambiguous meaning, but they introduce conceptual differences depending on the applied methodology and the type of precipitation variable estimated.

\section{Conclusions}

This study briefly presents the impact of the Guadalquivir River floods on the urban area of Seville, especially highlighting the city walls as a protective element against such events. These particular conditions influenced the levels of impacts cited in texts. From the literary description of the historical floods of the Guadalquivir River, we generated an index flood series from the late 13th century to the 19th century. In addition, we created transference criteria that numerically assigned three ascending levels of severity as a function of the described impacts. We developed graphs for each century that show the intensity of the floods and, complementarily, multi-annual sequences with no floods. Of the 10 floods classified as most destructive in the five centuries analyzed (1280-1880), five were concentrated during little more than a century (i.e., between 1598 and 1701).
We consider that a multiple-century application of floods is an adequate procedure that, in addition to other proxy data, contributes to the knowledge of the historical climatic evolution on the southern Iberian Peninsula.

\section{Acknowledgments}

We would like to thank the Royal Institute and Observatory of the Navy of San Fernando for providing records on precipitation from its historical archive. This study was partially funded by project PID2019104343RB-I00.

\section{References}

Alcoforado MJ, Nunes MF, García JC, Taborda JP. 2000. Temperature and precipitation reconstruction in southern Portugal during the late Maunder minimum (AD 1675-1715). The Holocene 10: 333-340. https://doi. org/10.1191/095968300674442959

Baena R, Rinaldi M, García-Martínez B, Guerrero-Amador I, Nardi L. 2019. Channel adjustments in the lower Guadalquivir River (southern Spain) over the last 250 years. Geomorphology 337: 15-30. https://doi. org/10.1016/j.geomorph.2019.03.027

Balasch JC, Pino D, Ruiz-Bellet JL, Tuset J, Barriendos M, Castelltort X, Peña JC. 2019. The extreme floods in the Ebro River basin since $1600 \mathrm{CE}$. Science of the Total Environment 646: 645-660. https://doi.org/10.1016/j. scitotenv.2018.07.325

Barriendos M, Martín-Vide J. 1998. Secular climatic oscillations as indicated by catastrophic floods in the Spanish Mediterranean coastal area (14th-19th centuries). Climatic Change 38: 473-491. https://doi. org/10.1023/A:1005343828552

Barriendos M, Rodrigo FS. 2006. Study of historical flood events on Spanish rivers using documentary data. Hydrological Sciences Journal 51: 765-783. https://doi. org/10.1623/hysj.51.5.765

Barriendos M. 2007. Climatic variability on Spain for past centuries. Reconstruction from historical documentary sources. In: Climate change in Andalusia: Evolution and environmental consequences (Sousa A, García-Barrón L, Jurado V, Eds.). Consejería de Medio Ambiente de la Junta de Andalucía, Seville, Spain, 45-54. Available at: http://www.juntadeandalucia.es/medioambiente/web/Bloques_Tematicos/ 
Educacion_Y_Participacion_Ambiental/Educacion_Ambiental/el_cambio_climatico_en_andalucia/ capitulo2.pdf

Barriendos M, Gil-Guirado S, Pino D, Tuset J, Pérez-Morales A, Alberola A, Costa J, Balasch JC, Castelltort X, Mazón J, Ruiz-Bellet JL. 2019. Climatic and social factors behind the Spanish Mediterranean flood event chronologies from documentary sources (14th-20th centuries). Global and Planetary Change 182: 102997. https://doi.org/10.1016/j.gloplacha.2019.102997

Benito G, Díez-Herrero A, Fernández de Villalta M. 2003. Magnitude and frequency of flooding in the Tagus basin (Central Spain) over the last millennium. Climatic Change 58: 171-192. https://doi. org/10.1023/A:1023417102053

Benito G. 2006. Riesgos de inundaciones: tendencias históricas y perspectivas de acuerdo con el cambio climático. Cuaternario y Geomorfología 20: 29-44. https://core.ac.uk/download/pdf/36016472.pdf

Benito G, Brázdil R, Herget J, Machado MJ. 2015. Quantitative historical hydrology in Europe. Hydrology and Earth System Sciences 19: 3517-3539. https://doi. org/10.5194/hess-19-3517-2015

Blöschl G, Kiss A, Viglione A, Barriendos M, Böhm O, Brázdil R, Coeur D, Demarée G, Llasat MC, Macdonald N, Retsö D, Roald L, Schmocker-Fackel P, Amorim I, Bělínová M, Benito G, Bertolin C, Camuffo D, Cornel D, Doktor R, Elleder L, Enzi S, Garcia JC, Glaser R, Hall J, Haslinger K, Hofstätter M, Komma J, Limanówka D, Lun D, Panin A, Parajka J, Petrić H, Rodrigo FS, Rohr C, Schönbein J, Schulte L, Silva LP, Toonen WHJ, Valent P, Waser J, Wetter O. 2020. Current European flood-rich period exceptional compared with past 500 years. Nature 583: 560-566. https://doi. org/10.1038/s41586-020-2478-3

Brázdil R, Kundzewicz ZW, Benito G. 2006. Historical hydrology for studying flood risk in Europe. Hydrological Sciences Journal 51: 739-764. https://doi.org/10.1623/ hysj.51.5.739

Cremades CV. 2017. Rogativas pro-pluvia y pro-serenitate en la cuenca del Segura durante la PEH: la información suministrada por el Archivo Diocesano de Orihuela. In: Riesgo, desastre y miedo en la península Ibérica y México durante la Edad Moderna (Alberola Romá A, Ed.). Universidad de Alicante/El Colegio de Michoacán, 47-69. Available at: https://rua.ua.es/dspace/bitstream/10045/71200/1/2017_Cremades-Prieto_Rogativas-pro-pluvia-y-pro-serenitate.pdf
Del Moral L. 1991. La obra hidráulica en la cuenca baja del Guadalquivir (siglos XVIII-XX). Gestión del agua y organización del territorio. Junta de Andalucía y Universidad de Sevilla, Spain.

Del Moral L. 1992. El Guadalquivir y la transformación urbana de Sevilla (siglos XVIII-XX). Ayuntamiento de Sevilla, Spain.

DGPCE. 2019. Catálogo nacional de inundaciones históricas. Dirección General de Protección Civil y Emergencias, Ministerio del Interior de España. Avalaible at: https://www.proteccioncivil.es/catalogo/ naturales/cnih/cnih2014/Presentacion.html (accessed on September 11, 2019).

Do Ó A, Roxo MJ. 2008. Drought events in Southern Portugal from the 12th to the 19th centuries: Integrated research from descriptive sources. Natural Hazards 47: 55-63. https://doi.org/10.1007/s11069-007-9196-0

Eddy JA. 1976. The Maunder minimum. Science 192: 11891202. https://doi.org/10.1126/science.192.4245.1189

Fernández-Fernández MI, Gallego MC, Domínguez-Castro F, Trigo RM, García JA, Vaquero JM, González JMM, Durán JC. 2014. The climate in Zafra from 1750 to 1840 : history and description of weather observations. Climatic Change 126: 107-118. https://doi. org/10.1007/s10584-014-1201-5

Fragoso M, Marques D, Santos JA, Alcoforado MJ, Amorim I, Garcia JC, Silva L, De Fátima Nunes M. 2015. Climatic extremes in Portugal in the 1780s based on documentary and instrumental records. Climate Research: 66: 141-159. https://doi.org/10.3354/cr01337

Gallego MC, García JA, Vaquero JM, Mateos VL. 2006. Changes in frequency and intensity of daily precipitation over the Iberian Peninsula. Journal of Geophysical Research 111: D24105. https://doi.org/10.1029/ 2006JD007280

García Codrón J. 2004. Las ciudades españolas y el riesgo de inundación: permanencia y cambio de un problema crónico. Boletín de la Asociación de Geógrafos Españoles 37: 85-99.

García Martínez B. 2003. Interpretación paleohidrológica (ss. XVI-XX) del tramo bajo continental del río Guadalquivir a través de sus inundaciones y meandros. In: Geografía de Andalucía. Asociación de Profesores de Geografía e Historia de Bachillerato de Andalucía, Spain, 173-213.

García-Barrón L, Aguilar-Alba M, Sousa A. 2011. Evolution of annual rainfall irregularity in the southwest of the Iberian Peninsula. Theoretical and Applied 
Climatology 103: 13-26. https://doi.org/10.1007/ s00704-010-0280-0

García-Barrón L, Morales J, Sousa A. 2013. Characterization of the intra-annual rainfall and its evolution (1837-2010) in the southwest of the Iberian Peninsula. Theoretical and Applied Climatology 114: 445-457. https://doi.org/10.1007/s00704-013-0855-7

García-Barrón L, Aguilar-Alba M, Morales J, Sousa A. 2018. Intra-annual rainfall variability in the Spanish hydrographic basins. International Journal of Climatology 38: 2215-2229. https://doi.org/10.1002/ joc. 5328

García-Martínez B, Baena R. 2006. El impacto de las infraestructuras de la ciudad de Sevilla sobre el paisaje fluvial del río Guadalquivir. In: Ríos y ciudades europeas: espacios naturales, culturales y productivos (Baena R, Guerrero I, Posada JC, López E, Eds.). I Encuentro Internacional de Ciudades Fluviales Europeas. Universidad de Sevilla, Spain, 119-128. Available at: https://idus.us.es/handle/11441/62088\#. XxWDv3p_at0.mendeley

Glaser R, Riemann D, Schönbein J, Barriendos M, Brázdil R, Bertolin C, Camuffo D, Deutsch M, Dobrovolný P, van Engelen A, Enzi S, Halíčková M, Koenig SJ, Kotyza O, Limanówka D, Macková J, Sghedoni M, Martin B, Himmelsbach I. 2010. The variability of European floods since AD 1500. Climatic Change 101: 235-256. https://doi.org/10.1007/ s10584-010-9816-7

Grove AT. 2001. The "Little Ice Age" and its geomorphological consequences in Mediterranean Europe. Climatic Change 48: 121-136. https://doi. org/10.1023/A:1005610804390

Kjeldsen TR, Macdonald N, Lang M, Mediero L, Albuquerque T, Bogdanowicz E, Brazdil R, Castellarin A, David V, Fleig A, Gül GO. 2014. Documentary evidence of past floods in Europe and their utility in flood frequency estimation. Journal of Hydrology 517: 963-973. https://doi.org/10.1016/j.jhydrol.2014.06.038

León P, García-Martínez B, Langa Nuño C. 2020. El estudio de las inundaciones históricas en Sevilla a través de fuentes periodísticas (siglo XX). Estudios sobre el Mensaje Periodístico 26: 177-188. https://doi. org/10.5209/esmp.67297

Luterbacher J, Xoplaki E, Dietrich D, Rickli R, Jacobeit J, Beck C, Gyalistras D, Schmutz C, Wanner H. 2002. Reconstruction of sea level pressure fields over the Eastern North Atlantic and Europe back to 1500. Cli- mate Dynamics 18: 545-562. https://doi.org/10.1007/ s00382-001-0196-6

Machado MJ, Benito G, Barriendos M, Rodrigo FS. 2011. 500 Years of rainfall variability and extreme hydrological events in southeastern Spain drylands. Journal of Arid Environments 75: 1244-1253. https:// doi.org/10.1016/j.jaridenv.2011.02.002

Martín-Vide J, Barriendos M. 1995. The use of rogation ceremony records in climatic reconstruction: a case study from Catalonia (Spain). Climatic Change 30: 201-221. https://doi.org/10.1007/BF01091842

Morbidelli R, García-Marín AP, Mamun AA, Atiqur RM, Ayuso-Muñoz JL, Taouti MB, Baranowski P, Bellocchi G, Sangüesa-Pool C, Bennett B, Oyunmunkh B, Bonaccorso B, Brocca L, Caloiero T, Caporali E, Caracciolo D, Casas-Castillo MC, Catalini CG, Chettih M, Chowdhury AFMK, Chowdhury R, Corradini C, Custò J, Dari J, Diodato N, Doesken N, Dumitrescu A, Estévez J, Flammini A, Fowler HJ, Freni G, Fusto F, García-Barrón L, Manea A, Goenster-Jordan S, Hinson S, Kanecka-Geszke E, Kar KK, Kasperska-Wołowicz W, Krabbi M, Krzyszczak J, Llabrés-Brustenga A, Ledesma JLJ, Liu T, Lompi M, Marsico L, Mascaro G, Moramarco T, Newman N, Orzan A, Pampaloni M, Pizarro-Tapia R, Torres AP, Rashid MDM, Rodríguez-Solà R, Manzor MS, Siwek K, Sousa A, Timbadiya PV, Filippo T, Vilcea MG, Viterbo F, Yoo C, Zeri M, Zittis G, Saltalippi C. 2020. The history of rainfall data time-resolution in a wide variety of geographical areas. Journal of Hydrology 590: 125258. https://doi. org/10.1016/j.jhydrol.2020.125258

Palomo y Rubio, Francisco de Borja. 1878. Historia crítica de las riadas o grandes avenidas del Guadalquivir en Sevilla: desde su reconquista hasta nuestros días. Francisco Álvarez y Compañía, Seville, Spain. Available at: http://www.bibliotecavirtualdeandalucia.es/catalogo/ es/consulta/registro. cmd?id $=7818$

Pfister C, Brázdil R, Glaser R, Barriendos M, Camuffo D, Deutsch M, Dobrovolný P, Enzi S, Guidoboni E, Kotyza O, Militzer S, Rácz L, Rodrigo FS. 1999. Documentary evidence on climate in sixteenth-century Europe. Climatic Change 43: 55-110. https://doi. org/10.1023/A:1005540707792

Rodrigo FS, Esteban-Parra MJ, Pozo-Vázquez D, Castro-Díez Y. 1999. A 500-year precipitation record in Southern Spain. International Journal of Climatology 19: 1233-1253. https://doi.org/10.1002/(SICI)10970088(199909)19:11<1233::AID-JOC413>3.0.CO;2-L 
Rodrigo FS, Esteban-Parra MJ, Pozo-Vázquez D, Castro-Díez Y. 2000. Rainfall variability in southern Spain on decadal to centennial time scales. International Journal of Climatology 20: 721-732. https://doi. org/10.1002/1097-0088(20000615)20:7<721::AIDJOC520>3.0.CO;2-Q

Rodrigo FS. 2002. Changes in climate variability and seasonal rainfall extremes: A case study from San Fernando (Spain), 1821-2000. Theoretical and Applied Climatology 72: 193-207. https://doi.org/10.1007/ s007040200020

Rodrigo FS. 2007. El clima de Andalucía a través de los registros históricos. In: Climate change in Andalusia: Evolution and environmental consequences (Sousa A, García-Barrón L, Jurado V, Eds.). Consejería de Medio Ambiente de la Junta de Andalucía, Sevilla, Spain, 25-41. Available at: http://www.juntadeandalucia.es/medioambiente/web/Bloques_Tematicos/ Educacion_Y_Participacion_Ambiental/Educacion_Ambiental/el_cambio_climatico_en_andalucia/ capitulo1.pdf

Rodrigo FS, Gómez-Navarro JJ, Montávez Gómez JP. 2012. Climate variability in Andalusia (southern Spain) during the period 1701-1850 based on documentary sources: Evaluation and comparison with climate model simulations. Climate of the Past 8: 117-133. https://doi.org/10.5194/cp-8-117-2012

Rodrigo FS. 2017. Variabilidad climática e inundaciones en Sevilla en la década de 1780 a partir de fuentes documentales. SÉMATA, Ciencias Sociais e Humanidades 29: 165-183.

Rodrigo FS. 2018. A review of the Little Ice Age in Andalusia (Southern Spain): results and research challenges. Cuadernos de investigación geográfica/Geographical Research Letters 44: 245-65. http://doi.org/10.18172/ cig.3316

Ruiz-Constán A, Ruiz-Armenteros AM, Galindo-Zaldívar J, Lamas-Fernández F, Sousa JJ, Sanz de Galdeano C, Pedrera A, Martos-Rosillo S, Caro Cuenca M, Delgado JM, Hanssen RF, Gil AJ. 2017. Factors determining subsidence in urbanized floodplains: evidence from MT-InSAR in Seville (southern Spain). Earth Surface Processes and Landforms 42: 2484-2497. https://doi. org/10.1002/esp.4180

Sousa A, García-Murillo P. 2003. Changes in the wetlands of Andalusia (Doñana Natural Park, SW Spain) at the end of the Little Ice Age. Climatic Change 58: 193-217. https://doi.org/10.1023/A:1023421202961
Sousa A, García-Murillo P, Morales J, García-Barrón L. 2009. Anthropogenic and natural effects on the coastal lagoons in the Southwest of Spain (Doñana Natural Park). ICES Journal of Marine Science 66: 1508-1514. https://doi.org/10.1093/icesjms/fsp106

Sousa A, García-Murillo P, Sahin S, Morales J, García-Barrón L. 2010. Wetland place names as indicators of manifestations of recent climate change in SW Spain (Doñana Natural Park). Climatic Change 100:525-557. https://doi.org/10.1007/s10584-009-9794-9

Sousa A, Morales J, García-Barrón L, García-Murillo P. 2013. Changes in the Erica ciliaris Loefl. ex L. peat bogs of southwestern Europe from the 17th to the 20th centuries. The Holocene 23: 255-269. https://doi. org/10.1177/0959683612455545

Sousa A, García-Barrón L, García-Murillo P, Vetter M, Morales J. 2015. The use of changes in small coastal Atlantic brooks in southwestern Europe as indicators of anthropogenic and climatic impacts over the last 400 years. Journal of Paleolimnology 53: 73-88. https://doi. org/10.1007/s10933-014-9809-z

Tejedor E, de Luis M, Barriendos M, Cuadrat JM, Luterbacher J, Saz MÁ. 2019. Rogation ceremonies: A key to understanding past drought variability in northeastern Spain since 1650. Climate of the Past 15: 1647-1664. https://doi.org/10.5194/cp-15-1647-2019

Trigo R, Pozo-Vázquez D, Osborn T, Castro-Díez Y, Gámiz-Fortis S, Esteban-Parra MJ. 2004. North Atlantic oscillation influence on precipitation, river flow and water resources in the Iberian Peninsula. International Journal of Climatology 24: 925-944. https://doi. org/10.1002/joc. 1048

Uribelarrea D, Benito G. 2008. Fluvial changes of the Guadalquivir river during the Holocene in Córdoba (Southern Spain). Geomorphology 100: 14-31. https:// doi.org/10.1016/j.geomorph.2007.04.037

Usokin IG. 2017. A history of solar activity over millennia. Living Reviews in Solar Physics 14: 3. https://doi. org/10.1007/s41116-017-0006-9

Vallejo I. 2000. Las inundaciones en la cuenca del Guadalquivir. Serie Geográfica 9: 133-149.

Vanney JR. 1970. L'hydrologie du bas Guadalquivir. Consejo Superior de Investigaciones Científicas (CSIC), Departamento de Geografía Aplicada, Madrid.

Wilhelm B, Ballesteros-Cánovas JA, Macdonald N, Toonen WHJ, Baker V, Barriendos M, Benito G, Brauer A, Corella JP, Denniston R, Glaser R, Ionita M, Kahle M, Liu T, Luetscher M, Macklin M, Mudelsee M, 
Munoz S, Schulte L, George SS, Stoffel M, Wetter O. 2019. Interpreting historical, botanical, and geological evidence to aid preparations for future floods. Wiley Interdisciplinary Reviews: Water 6: 1-22. https://doi. org/10.1002/wat2.1318
Zamora F. 2014. "Quando el agua llegare aquí Sevilla...". La avenida del río Guadalquivir en 1626 según un documento de la Biblioteca da Ajuda (Portugal). Historia. Instituciones. Documentos 41: 407-431. https:// doi.org/10.12795/hid.2014.i41.13 


\section{Supplementary material}

Appendix I. Impact and overflow levels applied to the three flood indices with which the historical floods of the Guadalquivir River between 1250 and 1800 A.D. were characterized, as well as the criteria and filters used to categorize the impacts.

\begin{tabular}{|c|c|c|c|c|}
\hline $\begin{array}{l}\text { Index } \\
\text { Flood }\end{array}$ & $\begin{array}{l}\text { Overflow level } \\
\text { and impact }\end{array}$ & Main criteria & Secondary criteria & $\begin{array}{l}\text { Filters to modulate the } \\
\text { classification of the } \\
\text { impact }\end{array}$ \\
\hline
\end{tabular}

I Closing the gates of the city of Seville and the spindles. Flooding of extramural neighborhoods, with the evacuation of the flood plain in the vicinity of Seville.

II Alarm in the city with the rampart or gates endangered. Collapsed buildings. Inundation in the lower intramural

a) Height reached by the overflow on the wall.

b) Damage caused by the collapse of buildings.

c) Number of people drowned.

areas.

III Serious generalized catastrophic situation in the entire city, except in higher areas.

The relevance with which

d) Evacuation of extramural buildings.

e) Livestock mortality. f) Effects on the floating bridge or on the ships in the harbour.

g) Rogations and other religious ceremonies. a flood appears in the compilation of events.

The recognition of a flood byte authors and comparisons with similar events.

Whether the floods are included in the main records or only in particular references. 
Appendix II. Years of significant Guadalquivir River flooding (1297-1876) with indication of the month of the maximum overflow of the river and estimated severity index. For the 13th and 14th centuries the historical source only indicates the year and during the 19th century the severity index is not applicable.

\begin{tabular}{|c|c|c|c|}
\hline Century & Year & Month & Index \\
\hline 13 th & 1297 & - & 3 \\
\hline \multirow[t]{6}{*}{14 th } & 1330 & - & 2 \\
\hline & 1351 & - & 1 \\
\hline & 1353 & - & 2 \\
\hline & 1363 & - & 1 \\
\hline & 1373 & - & 1 \\
\hline & 1383 & - & 2 \\
\hline \multirow[t]{5}{*}{ 15th } & 1403 & November & 3 \\
\hline & 1435 & February & 2 \\
\hline & 1481 & December & 1 \\
\hline & 1485 & February & 3 \\
\hline & 1488 & December & 1 \\
\hline \multirow{10}{*}{ 16th } & 1507 & November & 1 \\
\hline & 1522 & January & 1 \\
\hline & 1544 & January & 2 \\
\hline & 1554 & January & 2 \\
\hline & 1590 & March & 2 \\
\hline & 1591 & March & 1 \\
\hline & 1592 & December & 1 \\
\hline & 1595 & November & 3 \\
\hline & 1596 & Mai & 1 \\
\hline & 1597 & January & 1 \\
\hline \multirow[t]{10}{*}{17 th } & 1603 & December & 1 \\
\hline & 1608 & March & 1 \\
\hline & 1618 & March & 2 \\
\hline & 1626 & January & 3 \\
\hline & 1633 & September & 1 \\
\hline & 1642 & January & 1 \\
\hline & 1649 & April & 3 \\
\hline & 1683 & January & 3 \\
\hline & 1691 & March & 1 \\
\hline & 1697 & Mai & 1 \\
\hline
\end{tabular}


Appendix II. Years of significant Guadalquivir River flooding (1297-1876) with indication of the month of the maximum overflow of the river and estimated severity index. For the 13th and 14th centuries the historical source only indicates the year and during the 19th century the severity index is not applicable.

\begin{tabular}{|c|c|c|c|}
\hline Century & Year & Month & Index \\
\hline \multirow[t]{13}{*}{ 18th } & 1707 & March & 3 \\
\hline & 1709 & February & 1 \\
\hline & 1736 & April & 1 \\
\hline & 1739 & December & 1 \\
\hline & 1740 & January & 0 \\
\hline & 1745 & February & 1 \\
\hline & 1750 & October & 1 \\
\hline & 1758 & January & 3 \\
\hline & 1777 & February & 2 \\
\hline & 1784 & January & 2 \\
\hline & 1786 & March & 1 \\
\hline & 1792 & January & 1 \\
\hline & 1796 & November & 2 \\
\hline \multirow[t]{23}{*}{ 19th } & 1802 & December & - \\
\hline & 1804 & January & - \\
\hline & 1806 & April & - \\
\hline & 1821 & January & - \\
\hline & 1823 & January & - \\
\hline & 1830 & January & - \\
\hline & 1831 & January & - \\
\hline & 1838 & February & - \\
\hline & 1839 & December & - \\
\hline & 1841 & January & - \\
\hline & 1843 & March & - \\
\hline & 1845 & January & - \\
\hline & 1846 & January & - \\
\hline & 1852 & December & - \\
\hline & 1855 & March & - \\
\hline & 1856 & January & - \\
\hline & 1858 & November & - \\
\hline & 1860 & December & - \\
\hline & 1862 & January & - \\
\hline & 1866 & March & - \\
\hline & 1867 & January & - \\
\hline & 1872 & January & - \\
\hline & 1876 & December & - \\
\hline
\end{tabular}




\section{Appendix III. Other documentary sources consulted}

Ariño F de. 1873. Sucesos de Sevilla de 1592 á 1604 Imprenta de Rafael Tarascó y Lassa. Biblioteca virtual de Andalucía. Available at: http://www.bibliotecavirtualdeandalucia.es/catalogo/es/consulta/registro. cmd?id=1017773 (accessed on September 22, 2019).

Barrantes Maldonado P. 1868. Corónica de rey don Enrique Tercero deste nombre en la casa de Castilla y de León, que otros llaman el doliente, hijo del rey don Juan el primero. 1541. Biblioteca Digital Real Academia de la Historia. Available at: https://bibliotecadigital.rah. es/es/consulta/registro.do?control=RAH20100000502 (accessed on September 26, 2019).

Bernáldez A. 1870. Historia de los Reyes Católicos Don Fernando y Doña Isabel. S. XVII. Biblioteca virtual de Andalucía. Available at: http://www.bibliotecavirtualdeandalucia.es/catalogo/es/consulta/registro. cmd?id=1000499 (accessed on September 6, 2019).

Delgado F. 1785. Leccion histórico-político-médica de las enfermedades que pueden seguirse de resultas de la pasada inundacion del Guadalquivir. Memorias Académicas de la Real Sociedad de Medicina y demás ciencias de Sevilla, tomo III, pp. 58-77.

Nieto Piña C. 1785. Varias reflexiones sobre las inundaciones del río en Sevilla, sus efectos y causas evitables. Memorias Académicas. Tomo III. Archivo de la Regia Sociedad. Real Academia de Medicina, pp. 336-360.
Ortiz de Zúñiga D. 1677. Anales eclesiásticos y seculares de la muy noble y muy leal ciudad de Sevilla. Imprenta Real. Madrid. Biblioteca virtual Andalucía. Available at: http://www.bibliotecavirtualdeandalucia.es/catalogo/es/consulta/registro.cmd?id=1013983 (accessed on September 11, 2019).

Trigueros CM. 1784. La riada. Ofic. de Vázquez y Comp. Available at: https://archive.org/details/A253289 (accessed on September 11, 2019).

Vera Limón D. 1797. De los perjuicios médicos que causan las inundaciones del Guadalquivir, modo de precaver y de corregirlo. Memorias Académicas de la Regia Sociedad de Medicina y demás ciencias de Sevilla, leg. 1797.

Ximénez de Lorite B. 1778. Causas físicas de las inundaciones de Sevilla. Perjuicios que causan a la salud pública y modo de remediarlos. Academia de Medicina de Sevilla, leg. 1778.

Zapata C. 1787. Si el agua de los ríos en sus inundaciones tengan algunos perjuicios para el uso interno o externo de ellas, quáles sean, y modo de examinarlas. En: Memorias académicas de la Regia Sociedad de Medicina y demás Ciencias de Sevilla, V, leg. 1786, pp. 95-107 